\title{
Effect of zinc oxide nanoparticles on dams and embryo-fetal development in rats
}

\author{
This article was published in the following Dove Press journal: \\ International Journal of Nanomedicine \\ 15 December 2014 \\ Number of times this article has been viewed
}

\author{
Jeong-Sup Hong ${ }^{1,2}$ \\ Myeong-Kyu Park' \\ Min-Seok Kim' \\ Jeong-Hyeon Lim' \\ Gil-Jong Park' \\ Eun-Ho Maeng' \\ Jae-Ho Shin ${ }^{3}$ \\ Yu-Ri Kim ${ }^{4}$ \\ Meyoung-Kon $\mathrm{Kim}^{4}$ \\ Jong-Kwon Lee ${ }^{5}$ \\ Jin-A Park ${ }^{2}$ \\ Jong-Choon $\mathrm{Kim}^{6}$ \\ Ho-Chul Shin ${ }^{2}$
}

'Health Care Research Laboratory, Korea Testing and Research Institute, Gimpo, ${ }^{2}$ College of Veterinary Medicine, Konkuk University, Seoul, ${ }^{3}$ Department of Biomedical Laboratory Science, Eulji University, Seongnam-si, ${ }^{4}$ Department of Biochemistry and Molecular Biology, Korea University Medical School and College, Seoul, ${ }^{5}$ Toxicological Research Division, National Institute of Food and Drug Safety Evaluation, Chungcheongbuk-do, ${ }^{6} \mathrm{College}$ of Veterinary Medicine, Chonnam National University, Gwangju, Korea

Correspondence: Ho-Chul Shin Department of Veterinary Pharmacology and Toxicology, College of Veterinary

Medicine, Konkuk University, Hwayang-dong I, Kwangjin-gu,

Seoul I43-70I, Korea

Tel +82 24504056

Fax +82 24503037

Email hshin@konkuk.ac.kr
Abstract: This study investigated the potential adverse effects of zinc oxide nanoparticles $\left(\mathrm{ZnO}^{\mathrm{SM} 20[-]} \mathrm{NPs}\right.$; negatively charged, $\left.20 \mathrm{~nm}\right)$ on pregnant dams and embryo-fetal development after maternal exposure over the period of gestational days 5-19 with Sprague Dawley rats. $\mathrm{ZnO}^{\mathrm{SM} 20(-)} \mathrm{NPs}$ were administered to pregnant rats by gavage at $0 \mathrm{mg} / \mathrm{kg} / \mathrm{day}, 100 \mathrm{mg} /$ $\mathrm{kg} / \mathrm{day}, 200 \mathrm{mg} / \mathrm{kg} / \mathrm{day}$, and $400 \mathrm{mg} / \mathrm{kg} / \mathrm{day}$. All dams were subjected to caesarean section on gestational day 20, and all the fetuses were examined for external, visceral, and skeletal alterations. Toxicity in the dams manifested as significantly decreased body weight at $400 \mathrm{mg} /$ $\mathrm{kg} /$ day and decreased liver weight, and increased adrenal glands weight at $200 \mathrm{mg} / \mathrm{kg} / \mathrm{day}$ and $400 \mathrm{mg} / \mathrm{kg} /$ day. However, no treatment-related difference in the number of corpora lutea, the number of implantation sites, the implantation rate (\%), resorption, dead fetuses, litter size, fetal deaths, fetal and placental weights, and sex ratio were observed between the groups. Morphological examinations of the fetuses demonstrated no significant difference in the incidences of abnormalities between the groups. No significant difference was found in the $\mathrm{Zn}$ content of fetal tissue between the control and high-dose groups. These results showed that a 15-day repeated oral dose of $\mathrm{ZnO}^{\mathrm{SM} 20(-)}$ was minimally maternotoxic at dose of $200 \mathrm{mg} / \mathrm{kg} /$ day and $400 \mathrm{mg} / \mathrm{kg} /$ day.

Keywords: nanotoxicology, nanoparticles, zinc oxide, maternal toxicity, developmental toxicity, teratogenicity

\section{Introduction}

Zinc oxide $(\mathrm{ZnO})$ nanoparticles (NPs) are among the most commonly-utilized group of high-crystallinity nanomaterials. ${ }^{1}$ Most applications of $\mathrm{ZnO}$ powder exploit the reactivity of the oxide as a precursor to other $\mathrm{Zn}$ compounds. ${ }^{1}$

Consequently, $\mathrm{ZnO}$ is added into materials and products, including plastics, ceramics, glass, cement, rubber, lubricants, paints, ointments, adhesives, sealants, pigments, batteries, ferrites, fire retardants, and so on. ${ }^{1}$ Also, $\mathrm{ZnO}$ nanomaterials possess ultraviolet (UV)-shielding and antibacterial properties, deodorizing effects, and heat and UV light resistance, with a potential for a wide range of applications in cosmetics and sunscreens, ${ }^{2}$ in the food industry as additives and in packing, ${ }^{3,4}$ as fungicides in agriculture, ${ }^{5}$ and in biomedical applications as anticancer drugs. ${ }^{6,7}$ However, the human risk and toxicity mechanism is not well known.

$\mathrm{ZnO}$ is generally considered to be a material with low toxicity, since $\mathrm{Zn}$ is an essential trace element in the human body and is commonly present in foods or added as a nutritional supplement. However, it becomes hazardous upon inhalation of $\mathrm{ZnO}$ fumes (for example, metal fume fever) which is generated from $\mathrm{Zn}$ or $\mathrm{Zn}$ alloys upon melting and oxidation at a high temperature. Drinker et $\mathrm{al}^{8}$ and $\mathrm{Blanc}$ et $\mathrm{al}^{9}$ reported 
that higher concentrations of freshly generated $\mathrm{ZnO}$, as given in previous human inhalation exposure studies can produce symptomatic, physiologic, and hematologic effects, as well as elevations in certain peripheral blood and bronchoalveolar lavage cytokines. It should be noted that small-sized particles are more reactive and responsive than are bulk-sized particles because they have a higher proportion of atoms on their surface. ${ }^{10}$ Also, the surface energy of $\mathrm{ZnO}$ nanomaterials is very low, and the particles are well dispersed in various solvents, as well as in air. ${ }^{11}$ Therefore, exposure and uptake of $\mathrm{ZnO}$ NPs can occur through various routes. ${ }^{12}$

$\mathrm{ZnO}$ NPs have been investigated in diverse biological systems. Wang et $\mathrm{al}^{13}$ reported that acute inhalation in Wistar rats of $\mathrm{ZnO}$ NPs at $2.5 \mathrm{mg} / \mathrm{kg}$ body weight caused severe damages in liver and lung tissues. There was another report that nanoforms of different particles were more toxic than their micro counterparts after acute exposure via the oral route in mice. ${ }^{14}$ A previous study evaluated the acute oral toxicity in mice of $\mathrm{ZnO}$ NPs at a high-dose range (1-5 g/ kg body weight) and found decreased damages to the liver, spleen, and pancreas with increasing NP doses. ${ }^{15}$ In a dermal toxicity study, ${ }^{16}$ 28-day repeated dose of $\mathrm{ZnO}$ NPs caused collagen loss at a higher dose in the skin of Sprague Dawley (SD) rats in comparison with the tail. ${ }^{16}$ Liver, lung, and kidney were considered to be the main target organs in a pharmacokinetic and tissue distribution study. ${ }^{10}$ Also, Yan et al $^{17}$ suggested that $\mathrm{ZnO}$ NPs could disturb the energy metabolism and cause mitochondria and cell membrane impairments in rat kidney, which may contribute to $\mathrm{ZnO}$ NP-induced nephrotoxicity. In spite of the fact that the increased use and production of $\mathrm{ZnO}$ NPs may results in health impacts due to environmental contaminations, the potential adverse effects of ultrafine $\mathrm{ZnO}$ on pregnant dams and embryo-fetal development have never been determined.

Currently, there is a serious lack of information on the potential NP hazard to human health, particularly on their possible toxic effects on the endocrine system, and existing data and knowledge of potential endocrine interactions and toxicities are quite limited (for example, reprotoxicity). ${ }^{18,19}$ Some studies of reproductive function suggest that exposure to some nanomaterials may disrupt endocrine functions, such as the regulation of serum sex hormone levels. In contrast, other nanomaterials may prevent endocrine dysfunction via various mechanisms, including antioxidant effects. ${ }^{18}$ Also, a lot of evidence shows that fetuses are affected more than adults by a variety of environmental toxins because of physiological immaturity. Yamashita and Yoshioka ${ }^{20}$ reported that nanosilica $(70 \mathrm{~nm})$ induced fetal resorption and restricted fetal growth, and that the surface modification of nanosilica with carboxyl or amine groups prevented resorption and fetal growth restriction in the study of nanosilica $(70 \mathrm{~nm})$. Therefore, studies of reproductive function are necessary to evaluate the potential endocrine-disrupting risks of nanomaterials, as well as their effects on fetuses and pregnancies.

The present study was undertaken to investigate the potential adverse effects of $20 \mathrm{~nm}$ negatively-charged $\mathrm{ZnO}$ NPs $\left(\mathrm{ZnO}^{\mathrm{SM} 20[-]} \mathrm{NPs}\right)$ on pregnant dams and embryo-fetal development in SD rats. The results of this investigation provide additional relevant information about the safety evaluation of $\mathrm{ZnO}^{\mathrm{SM} 20(-)} \mathrm{NP}$ exposures during pregnancy in SD rats.

\section{Materials and methods}

This study was performed in compliance with the Organization for Economic Cooperation and Development (OECD) test guideline 414 entitled to Prenatal Developmental Toxicity Study ${ }^{21}$ and in accordance with the Good Laboratory Practice (GLP) principle. ${ }^{22,23}$ The GLP process was performed in accordance with the standard operation procedures certified by the facility management. All of the animals were cared for as specified in the "Guide for the Care and Use of Laboratory Animals" issued by the Animal Care and Use Committee of the National Veterinary Research and Quarantine Service.

\section{Characterization of zinc oxide nanoparticles (ZnO NPs)}

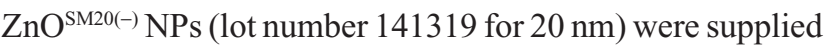
from Sumitomo-Osaka Cement Co., Ltd. (Tokyo, Japan), which had a $100.1 \%$ assay analysis and also contained $<1 \mathrm{ppm}$ $\mathrm{Fe}: \mathrm{ND}$ and $1.5 \mathrm{ppm} \mathrm{As}_{2} \mathrm{O}_{3}$. $\mathrm{ZnO}$ NPs were capped with citrate molecules, which were widely used as capping agents for inorganic NPs, giving rise to the charge surface property. ${ }^{24-26}$

\section{Animals and dosage}

$\mathrm{Crl}: \mathrm{CD}$ (SD) rats are commonly used in toxicity studies, as they have a large amount of reference data that have accumulated for a long period of time. Male and nulliparous female rats aged 10 weeks were obtained from a specific pathogenfree colony at Orient Bio Inc. (Gyeonggi-do, Korea) and used after 12 days of quarantine and acclimatization. The animals were housed in a room that was maintained at a temperature of $20.8^{\circ} \mathrm{C}-23.0^{\circ} \mathrm{C}$ and a relative humidity of $45.3 \%-56.9 \%$ with artificial lighting from 8 am to 8 pm and with 10-15 times air changes per hour. Normally, 1:1 (one male to one female) mating was used in this study. Each morning, the 
female rats were examined for the presence of sperms or a vaginal plug. Day 0 of pregnancy was defined as the day when vaginal plugs or sperm were found. The mated females were housed individually in clear polycarbonate cages with stainless steel wire lids. They were allowed sterilized tap water after UV irradiation and were fed on commercial rodent chow (Cargill Agri Purina, Inc., Gyeonggi-do, Korea) ad libitum.

For the oral administration of $\mathrm{ZnO}^{\mathrm{SM} 20(-)} \mathrm{NPs}$, the NPs were suspended in $20 \mathrm{nM}$ 4-(2-hydroxyethyl)-1-piperazine ethanesulfonic acid (HEPES) buffer containing 1\% sodium citrate (vehicle) and then mixed well. The final $\mathrm{pH}$ of the buffer solution was adjusted with $1 \mathrm{M}$ sodium carbonate,

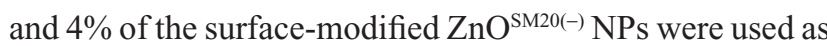
a stock solution. Before administration, the suspension was stirred for 10 seconds and then diluted with distilled water. The concentration of the dosing solution was measured on gestational days (GDs) 5, 11, and 19 using inductive coupled plasma atomic emission spectrometry (ICP-AES) (ULTIMA-2; HORIBA Ltd., Kyoto, Japan).

The test mixture was administered daily by gavage to the pregnant rats from GD 5 through GD 19 with a dose volume of $10 \mathrm{~mL} / \mathrm{kg}$ body weight. The vehicle control group received only a HEPES/citrate buffer solution with gavage. The daily application volume was calculated in advance, based on the most recently recorded body weight of the individual animal.

\section{Dose range finding study}

In a previous dose range finding study, a 14-day repeated oral dose of $\mathrm{ZnO}^{\mathrm{SM} 20(-)}$ NPs showed a decrease of body weight and changes in hematology and biochemistry parameters for $1,000 \mathrm{mg} / \mathrm{kg} / \mathrm{day}$ and $2,000 \mathrm{mg} / \mathrm{kg}$ /day groups. In the case of $\mathrm{ZnO}^{\mathrm{SM} 20(+)}$, death was observed in two male rats from the $2,000 \mathrm{mg} / \mathrm{kg} /$ day group. Body weight decrease, food consumption loss, and change of hematology and biochemistry parameters were observed from the $1,000 \mathrm{mg} / \mathrm{kg} /$ day and $2,000 \mathrm{mg} / \mathrm{kg} /$ day groups. In a subchronic toxicity study of 90 days of repeated oral treatment of $\mathrm{ZnO}^{\mathrm{SM} 20(-)}$, decreased food and water consumption was observed from the $125 \mathrm{mg} / \mathrm{kg} /$ day, $250 \mathrm{mg} / \mathrm{kg} /$ day, and $500 \mathrm{mg} / \mathrm{kg} /$ day groups, and weight reduction of the thymus, atrophy of the testis and seminal vesicle, as well as changes in the hematology and biochemistry parameters were observed from the $250 \mathrm{mg} / \mathrm{kg} /$ day and $500 \mathrm{mg} / \mathrm{kg} /$ day groups. Moreover, a repeated oral dose of $\mathrm{ZnO}^{\mathrm{SM} 20(+)}$ caused aninar cell apoptosis, submucosal edema, and inflammation in the glandular stomach, as well as decreases in the total protein and albumin for the $250 \mathrm{mg} / \mathrm{kg} /$ day and $500 \mathrm{mg} / \mathrm{kg} /$ day groups. When either a single oral dose or 90 -day repeated oral dose (vehicle control, $125 \mathrm{mg} / \mathrm{kg} /$ day, $250 \mathrm{mg} / \mathrm{kg} /$ day, and $500 \mathrm{mg} / \mathrm{kg} /$ day) study was performed for pharmacokinetic investigations, $\mathrm{Zn}$ concentrations in plasma increased among the $125 \mathrm{mg} / \mathrm{kg} /$ day, $250 \mathrm{mg} / \mathrm{kg} /$ day, and $500 \mathrm{mg} / \mathrm{kg} /$ day groups. ${ }^{27}$ Therefore, for the prenatal and developmental toxicity study, the high dose was set to $400 \mathrm{mg} / \mathrm{kg} /$ day of body weight and the middle and low doses were set to $200 \mathrm{mg} / \mathrm{kg} /$ day and $100 \mathrm{mg} / \mathrm{kg} /$ day, respectively.

\section{Experimental groups}

A total of 92 healthy female rats were assigned randomly to four experimental groups, as follows: three treatment groups received $\mathrm{ZnO}^{\mathrm{SM} 20(-)} \mathrm{NPs}$ at $100 \mathrm{mg} / \mathrm{kg} /$ day (number $[\mathrm{n}]=21) ; 200 \mathrm{mg} / \mathrm{kg} /$ day $(\mathrm{n}=24)$; and $400 \mathrm{mg} / \mathrm{kg} /$ day $(\mathrm{n}=25)$; and there was a vehicle control group $(n=22)$ (inseminated females per group). The doses selected for this study were based on the results of a dose range finding study conducted in our laboratory.

\section{Observation of dams}

All pregnant females were observed daily throughout the gestation period for clinical signs (mortality, morbidity, general appearance, and behavior). Maternal body weights were measured daily from GDs 0-20, and individual food consumptions were determined on GDs $0,2,4,6,8,10,12$, 14, 16, and 18. At the scheduled termination day (GD 20), all of the pregnant females were euthanized by isoflurane inhalation and exsanguination from the aorta. A complete gross postmortem examination was then performed. The absolute and relative (organ-to-body weight ratio) weights of the liver, heart, brain, kidneys, ovaries, spleen, lung, uteral cornua, adrenal glands, and pituitary were measured.

\section{Postmortem examination}

The ovaries and uteri of each female were removed and examined for the number of corpora lutea, as well as for the status of all the implantation sites (ie, live and dead fetuses, early and late resorptions, and total implantations). The uteri with no evidence of implantation were stained with a $2 \%$ sodium hydroxide solution to identify the presence of early resorption sites. ${ }^{28}$ If no stained implantation sites were present, the rat was considered "not pregnant".

On GD 20, dams were subjected to caesarean section. Following the measurement of gravid uterine weight, the number of corpora lutea, implantation, live fetuses, fetal resorptions, and dead fetuses were counted and recorded. Based on the results, the following were calculated. 
- Preimplantation loss (\%):

[n of corpora lutea - n of implantations/ $\mathrm{n}$ of corpora lutea] $\times 100$

- Postimplantation loss (\%):

[n of implantations $-\mathrm{n}$ of live fetuses/ $\mathrm{n}$ of implantations] $\times 100$

- Fetal death $=$ Resorptions + Dead fetuses.

Resorption was classified as "early" only when a resorption site resembling a dark brown blood clot and with no embryonic tissue was visible; it was considered "late" when both the placental and embryonic tissues were visible at the postmortem examination. All live fetuses were weighed individually, and their sexes were determined. They were examined for any morphological abnormalities, including a cleft palate. Alternate fetuses were selected for either a skeletal or visceral examination. Half of the live fetuses from each litter were fixed in absolute ethanol, eviscerated, and then processed for skeletal staining with Alizarin red $\mathrm{S}$ and Alcyan blue, and were used for subsequent skeletal examination. ${ }^{29}$ The other half was preserved in Bouin's solution and examined for internal soft tissue changes, using a freehand razor sectioning technique ${ }^{30}$ and Nishimura's method. ${ }^{31}$ The fetal morphological alterations observed in this study were classified as developmental malformations or variations. A malformation was defined as a permanent structural change, which would adversely affect survival or health. ${ }^{32}$ The term "variation" was defined as a change that occurred within the normal population under investigation, and that would not adversely affect survival or health. The suggested terminology in an internationally developed glossary of terms was used to classify the structural developmental abnormalities in common laboratory mammals. ${ }^{33}$

\section{Zn concentration in fetal tissue}

To investigate the placenta transfer of $\mathrm{ZnO}^{\mathrm{SM} 20(-)} \mathrm{NPs}$ in vivo, four extra female rats were used in the control $(n=2)$ and $400 \mathrm{mg} / \mathrm{kg} /$ day groups $\left(\mathrm{ZnO}^{\mathrm{SM} 20[-]} \mathrm{NPs} ; \mathrm{n}=2\right)$, respectively. Dosing occurred for the period of GDs 5-19 in the same manner as was used for the main study animals. On GD 20, fetuses were collected by caesarean sections from dams, and $\mathrm{Zn}$ contents in the fetal tissues were analyzed. Fetuses were digested in concentrated nitric acid overnight. The next day, nitric acid and perchloric acid were added to each sample and heated at $200^{\circ} \mathrm{C}-250^{\circ} \mathrm{C}$ until the solutions were colorless and clear. The concentrated sample solutions were put into a $100 \mathrm{~mL}$ volumetric flask, which was filled with purified water to the marked line. Before analysis, ICP-AES
(HORIBA Ltd.) was calibrated every time by running at least six Zn standard concentrations $(0.5 \mathrm{mg} / \mathrm{L}, 2 \mathrm{mg} / \mathrm{L}, 5 \mathrm{mg} / \mathrm{L}$, $10 \mathrm{mg} / \mathrm{L}, 20 \mathrm{mg} / \mathrm{L}$, and $40 \mathrm{mg} / \mathrm{L})$.

\section{Data analysis}

The evaluation item, the statistical analysis was performed on the pregnant rats or fetuses. ${ }^{34}$ Quantitative continuous data, such as maternal body weight, food consumption, fetal body weight, and placental weight, were subjected to a one-way analysis of variance (ANOVA), and a Scheffe's multiple comparison test was carried out when the differences were significant. ${ }^{35}$ The number of corpora lutea, total implantations, live and dead fetuses, and fetal alterations were statistically evaluated using the Kruskal-Wallis nonparametric ANOVA, ${ }^{36}$ followed by the Mann-Whitney $U$-test, where appropriate. The sex ratio and the proportions of litters with malformations and developmental variations were compared using a chi-square test and Fisher's exact probability test. ${ }^{37}$ Statistical analyses were performed by comparing the treatment groups with the control group using SPSS 19.0 software (IBM Corporation, Armonk, NY, USA). A difference with a $P$-level $\leq 0.05$ was considered statistically significant.

\section{Results}

\section{Formulation analysis of $\mathrm{ZnO}$ NPs}

Table 1 summarizes the concentrations of the dosing solution for $\mathrm{ZnO}^{\mathrm{SM} 20(-)} \mathrm{NPs}$ on GDs 5, 11, and 19. Three analyses

Table I Formulation analysis of the dosing solution for $\mathrm{ZnO}^{\text {SM20(-) }}$ NPs on GDs 5, II, and 19

\begin{tabular}{|c|c|c|c|}
\hline \multirow{2}{*}{$\begin{array}{l}\text { Dosing } \\
\text { date }\end{array}$} & \multicolumn{3}{|l|}{$\mathbf{Z n O}^{\text {SM20(-) }}$} \\
\hline & $\begin{array}{l}\text { Target } \\
\text { concentration } \\
(\mathrm{mg} / \mathrm{mL})\end{array}$ & $\begin{array}{l}\text { Determined } \\
\text { concentration } \\
(\mathrm{mg} / \mathrm{mL})\end{array}$ & $\begin{array}{l}\text { Difference } \\
\text { from target (\%) }\end{array}$ \\
\hline GD 5 & 0 & Not detected & Not detected \\
\hline GD II & 0 & Not detected & Not detected \\
\hline GD 19 & 0 & Not detected & Not detected \\
\hline GD 5 & 10 & 9.32 & -6.82 \\
\hline GD II & 10 & 9.93 & -0.67 \\
\hline \multirow[t]{2}{*}{ GD 19} & 10 & 10.25 & 2.50 \\
\hline & & $9.83 \pm 0.47^{\mathrm{a}}$ & \\
\hline GD 5 & 20 & 17.20 & -14.00 \\
\hline GD I I & 20 & 20.35 & 1.77 \\
\hline \multirow[t]{2}{*}{ GD 19} & 20 & 20.50 & 2.50 \\
\hline & & $19.35 \pm 1.86^{\mathrm{a}}$ & \\
\hline GD 5 & 40 & 38.38 & -4.06 \\
\hline GD I I & 40 & 41.40 & 3.49 \\
\hline \multirow[t]{2}{*}{ GD 19} & 40 & 39.79 & -0.52 \\
\hline & & $39.86 \pm 1.5 \mathrm{I}^{\mathrm{a}}$ & \\
\hline
\end{tabular}

Note: ${ }^{V}$ alues are expressed as the mean \pm standard deviation.

Abbreviations: $\mathrm{ZnO}^{\mathrm{SM20}(-)}, 20 \mathrm{~nm}$ negatively-charged $\mathrm{ZnO}$; NPs, nanoparticles; $\mathrm{GD}$, gestation day. 


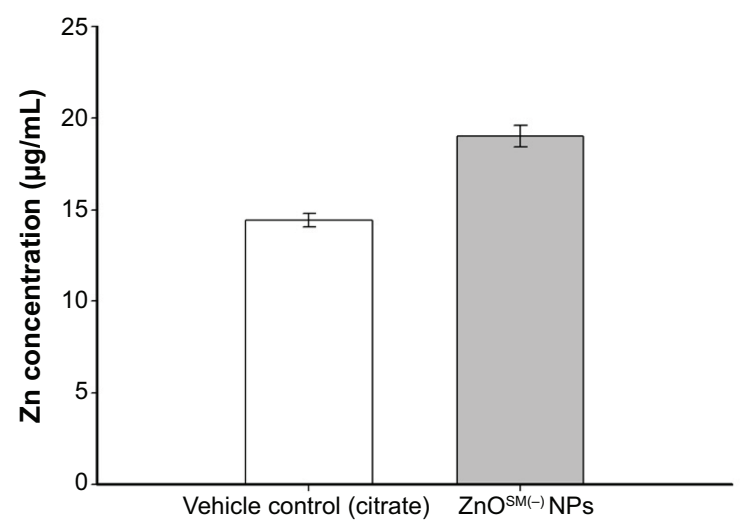

Figure I The total Zn levels measured with ICP-AES.

Notes: To investigate the placenta transfer of $\mathrm{ZnO}^{\mathrm{SM} 20(-)} \mathrm{NPs}$ in vivo, four extra female rats were used in the nontreatment control group $(n=2)$ and $400 \mathrm{mg} / \mathrm{kg} / \mathrm{day}$ groups $\left(\mathrm{ZnO}^{\mathrm{SM20[}[-]} \mathrm{NPs} ; \mathrm{n}=2\right)$, respectively. Dosing occurred on GDs 5-19 in the same manner as for the main study animals.

Abbreviations: $\mathrm{ZnO}^{\mathrm{SM} 2(-)}, 20 \mathrm{~nm}$ negatively-charged $\mathrm{ZnO}$; NPs, nanoparticles; ICP-AES, inductive coupled plasma atomic emission spectrometry; n, number; GD, gestational day.

confirmed that the concentrations of all dose formulations were within $\pm 15 \%$ of the target concentrations. $\mathrm{ZnO}^{\mathrm{SM} 20(-)}$ NPs were stable for 4 hours at room temperature. Concentrations of total $\mathrm{Zn}$ were $9.83 \pm 0.47 \mathrm{mg} / \mathrm{mL}$ (mean \pm standard deviation) for the $100 \mathrm{mg} / \mathrm{kg} /$ day group, $19.35 \pm 1.86 \mathrm{mg} / \mathrm{mL}$ for the $200 \mathrm{mg} / \mathrm{kg} /$ day group, and $39.86 \pm 1.51 \mathrm{mg} / \mathrm{mL}$ for the $400 \mathrm{mg} / \mathrm{kg}$ /day group.

\section{Zn concentration in fetal tissue}

The $\mathrm{Zn}$ concentrations in fetal tissues are shown in Figure 1. The measured total $\mathrm{Zn}$ levels with ICP-AES was $14.44 \pm 0.37 \mu \mathrm{g} / \mathrm{g}$ (mean \pm standard deviation) for the control group, and $19.02 \pm 0.60 \mu \mathrm{g} / \mathrm{g}\left(\mathrm{ZnO}^{\mathrm{SM} 20[-]} \mathrm{NPs}\right)$ for the $400 \mathrm{mg} / \mathrm{kg} /$ day group (Table 2). The $\mathrm{Zn}$ contents in fetuses after in utero exposure to $\mathrm{ZnO}^{\mathrm{SM} 20(-)} \mathrm{NPs}$ were not significantly different from the $\mathrm{Zn}$ contents in control fetuses.

\section{Effects on dams}

Six of $21 \mathrm{dams}$ from the $100 \mathrm{mg} / \mathrm{kg} /$ day group, ten of 23 dams from the $200 \mathrm{mg} / \mathrm{kg} /$ day group, and 16 of 25 dams from the $400 \mathrm{mg} / \mathrm{kg} /$ day group showed salivation around mouth in terms of their general appearance, but it was transiently observed after treatment. Also, alopecia (localized areas of partial alopecia) was observed in two pregnant rats from the vehicle control group, one from the $100 \mathrm{mg} / \mathrm{kg} /$ day group, one from the $200 \mathrm{mg} / \mathrm{kg}$ /day group, and two from the $400 \mathrm{mg} / \mathrm{kg}$ / day group, starting from 6-10 days after oral administration (data not shown). This clinical sign was not recovered during the treatment period. The changes in body weight during the entire experimental period are shown in Figure 2. As shown in the data of Table 3, the maternal body weight on GD 20 in the high-dose group was significantly decreased when compared with the vehicle control group. The maternal body weight gain during pregnancy $(P<0.05)$ and corrected body weight $(P<0.01)$ were also significantly lower than those for the control group. There was no statistically significant difference in food consumption between the control and treatment groups (Table 4). At the scheduled autopsy, no treatment-related gross finding was observed in the dams from all groups. The absolute and relative organ weights of the pregnant rats, treated with $\mathrm{ZnO}^{\mathrm{SM} 20(-)} \mathrm{NPs}$, are presented in Table 5. The relative liver weight in the $200 \mathrm{mg} / \mathrm{kg} /$ day group, and the absolute and relative liver weights in the $400 \mathrm{mg} / \mathrm{kg} /$ day group were significantly decreased in a dose-dependent manner in comparison with those of the vehicle control group. Absolute and relative weights of the right adrenal gland in

Table 2 The $\mathrm{Zn}$ content in fetuses after in utero exposure to $\mathrm{ZnO}^{\mathrm{SM20(-)}} \mathrm{NPs}$

\begin{tabular}{|c|c|c|c|}
\hline \multirow[t]{2}{*}{ Parameters } & \multirow[t]{2}{*}{ Unit } & \multicolumn{2}{|c|}{ Dose (mg/kg body weight/day) } \\
\hline & & $\begin{array}{l}\text { Nontreatment } \\
\text { control group }\end{array}$ & $\begin{array}{l}400 \mathrm{mg} / \mathrm{kg} \text { treatment } \\
\left.\text { (ZnO }{ }^{\mathrm{sM20}-]} \mathrm{NPs}\right)\end{array}$ \\
\hline Number of fetuses/pregnant females & Fetus & $28 / 2$ & $24 / 2$ \\
\hline \multirow[t]{3}{*}{ Concentration } & $(\mu g / m L)$ & 9.04 & 9.24 \\
\hline & $(\mu g / m L)$ & 6.77 & 8.64 \\
\hline & $(\mu g / m L)$ & $7.91 \pm 1.6 I^{\mathrm{a}}$ & $8.94 \pm 0.42^{\mathrm{a}}$ \\
\hline Dilution & & 100.00 & 100.00 \\
\hline \multirow[t]{3}{*}{ Sample weight } & $(g)$ & 63.75 & 49.71 \\
\hline & $(g)$ & 46.05 & 44.45 \\
\hline & $(g)$ & $54.90 \pm 0.37^{a}$ & $47.08 \pm 3.72^{\mathrm{a}}$ \\
\hline \multirow[t]{3}{*}{ Conversion concentration } & $(\mu g / g)$ & 14.18 & 18.59 \\
\hline & $(\mu g / g)$ & 14.70 & 19.44 \\
\hline & $(\mu g / g)$ & $14.44 \pm 0.37^{\mathrm{a}}$ & $19.02 \pm 0.60^{\mathrm{a}}$ \\
\hline
\end{tabular}

Note: ${ }^{a}$ Values are expressed as the mean \pm standard deviation.

Abbreviations: $\mathrm{ZnO}^{\mathrm{SM} 20(-)}, 20 \mathrm{~nm}$ negatively-charged $\mathrm{ZnO}$; NPs, nanoparticles. 


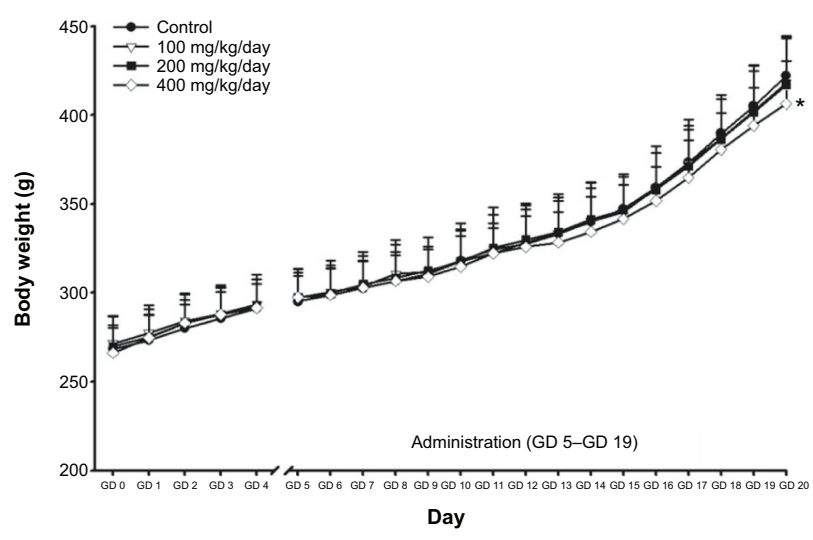

Figure 2 Body weight changes of female rats during the gestation period.

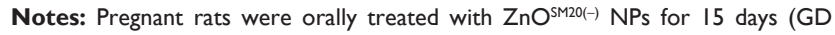
5-GD 19) with doses of $100 \mathrm{mg} / \mathrm{kg} /$ day, $200 \mathrm{mg} / \mathrm{kg} /$ day, and $400 \mathrm{mg} / \mathrm{kg} /$ day. GD 0 means the day of pregnancy. "GD" is the day after gestation. Statistically different from the vehicle control group; $* P<0.05$.

Abbreviations: GD, gestational day; $\mathrm{ZnO}^{\mathrm{SM} 20(-)}, 20 \mathrm{~nm}$ negatively-charged $\mathrm{ZnO}$; NPs, nanoparticles.

the $200 \mathrm{mg} / \mathrm{kg} /$ day and $400 \mathrm{mg} / \mathrm{kg} /$ day groups and relative weights of the left adrenal gland in the $400 \mathrm{mg} / \mathrm{kg}$ /day group were significantly increased in a dose-dependent manner in comparison with the vehicle control group.

\section{Effects on embryo-fetal development}

Table 6 summarized the reproductive findings among the pregnant rats treated with $\mathrm{ZnO}^{\mathrm{SM} 20(-)} \mathrm{NPs}$ on GD 5-19. The overall pregnancy rates were similar for all dosage groups, ranging from $84 \%-100 \%$. No totally resorbed litter was found in any group. The number of corpora lutea, implantations, implantation rates, fetal deaths, and sex ratios of the live fetuses were similar for the treatment groups and the vehicle control group. No significant difference between the treatment and control groups was seen for placental weight and fetal weight. There were no fetuses with external malformations. The observed external variations in the treatment groups were hematoma, hyperplasia of the tail, and short tail. However, the numbers of fetuses with external variations were not significantly increased in comparison to the control group (Table 7). Although there were some types of visceral variations, including misshapen thymus, ureter abnormality (grade I: slight dilation of the renal pelvis; grade II: reduced papilla size and noticeable dilation of the renal pelvis; and Grade III: very short or no papillae and a marked dilation of the renal space), ${ }^{38}$ dilated renal pelvis, large kidney, and ectopic kidney

Table 3 Body weights of the pregnant rats treated with $\mathrm{ZnO}^{\text {SM20(-) NPs }}$

\begin{tabular}{|c|c|c|c|c|}
\hline \multirow[t]{2}{*}{ Dose (mg/kg body weight/day) } & \multicolumn{4}{|l|}{$\mathrm{ZnO}^{\text {SM20(-) NPs }}$} \\
\hline & Vehicle (citrate) & 100 & 200 & 400 \\
\hline Number of pregnant females & 22 & 21 & 24 & 25 \\
\hline Gestation day 0 & $268.5 \pm 13.16^{\mathrm{a}}$ & $271.5 \pm 15.10$ & $269.7 \pm 17.40$ & $266.2 \pm 13.99$ \\
\hline Gestation day I & $273.3 \pm 14.07$ & $277.4 \pm 15.77$ & $274.9 \pm 16.04$ & $274.7 \pm 13.10$ \\
\hline Gestation day 2 & $280.0 \pm 13.52$ & $284.2 \pm 15.73$ & $282.8 \pm 16.33$ & $283.0 \pm 13.1 \mid$ \\
\hline Gestation day 3 & $285.6 \pm 15.09$ & $288.0 \pm 16.18$ & $287.7 \pm 15.08$ & $287.8 \pm 15.18$ \\
\hline Gestation day 4 & $291.3 \pm 16.18$ & $293.3 \pm 17.02$ & $292.8 \pm 15.03$ & $291.6 \pm 13.34$ \\
\hline Gestation day 5 & $295.1 \pm 14.53$ & $297.0 \pm 16.70$ & $297.4 \pm 15.88$ & $297.6 \pm 13.96$ \\
\hline Gestation day 6 & $298.6 \pm 15.25$ & $300.5 \pm 17.57$ & $299.6 \pm 15.93$ & $298.8 \pm 14.69$ \\
\hline Gestation day 7 & $302.7 \pm 15.42$ & $303.7 \pm 19.13$ & $304.8 \pm 15.85$ & $302.9 \pm 15.00$ \\
\hline Gestation day 8 & $306.6 \pm 16.22$ & $310.5 \pm 19.29$ & $308.4 \pm 18.74$ & $306.7 \pm 14.56$ \\
\hline Gestation day 9 & $310.7 \pm 15.33$ & $311.9 \pm 19.41$ & $312.5 \pm 18.86$ & $309.0 \pm 15.38$ \\
\hline Gestation day 10 & $317.8 \pm 17.95$ & $318.1 \pm 20.85$ & $317.5 \pm 17.52$ & $314.7 \pm 17.34$ \\
\hline Gestation day II & $322.3 \pm 14.33$ & $324.5 \pm 23.58$ & $325.1 \pm 18.82$ & $322.2 \pm 16.76$ \\
\hline Gestation day 12 & $328.3 \pm 18.76$ & $327.6 \pm 22.71$ & $329.9 \pm 19.20$ & $325.9 \pm|7.2|$ \\
\hline Gestation day 13 & $333.4 \pm 18.41$ & $333.3 \pm 22.34$ & $334.2 \pm 19.61$ & $328.4 \pm 17.16$ \\
\hline Gestation day 14 & $340.0 \pm 18.81$ & $340.4 \pm 21.64$ & $341.2 \pm 21.27$ & $334.4 \pm 19.80$ \\
\hline Gestation day 15 & $347.3 \pm 18.16$ & $345.4 \pm 21.35$ & $346.7 \pm 20.08$ & $341.6 \pm 19.29$ \\
\hline Gestation day 16 & $359.2 \pm 19.59$ & $359.1 \pm 23.33$ & $358.1 \pm 20.70$ & $351.9 \pm 19.12$ \\
\hline Gestation day 17 & $373.3 \pm 18.56$ & $372.8 \pm 24.77$ & $371.3 \pm 22.73$ & $364.8 \pm 21.29$ \\
\hline Gestation day 18 & $389.8 \pm 19.50$ & $386.9 \pm 24.29$ & $386.5 \pm 24.77$ & $380.7 \pm 20.49$ \\
\hline Gestation day 19 & $405.1 \pm 19.83$ & $402.4 \pm 25.97$ & $401.7 \pm 26.26$ & $394.1 \pm 21.42$ \\
\hline Gestation day 20 & $422.2 \pm 20.86$ & $418.3 \pm 26.38$ & $417.1 \pm 26.73$ & $406.4 \pm 23.97 *$ \\
\hline Weight gain during pregnancy & $153.8 \pm 13.93$ & $146.9 \pm 18.58$ & $147.4 \pm 18.83$ & $|40.2 \pm 20.1|^{*}$ \\
\hline Corrected body weight & $340.5 \pm 19.77$ & $338.3 \pm 22.70$ & $332.9 \pm 22.28$ & $320.6 \pm 21.14^{* *}$ \\
\hline Gravid uterine weight & $81.8 \pm 8.62$ & $80.1 \pm 8.80$ & $84.2 \pm 9.67$ & $85.8 \pm 12.99$ \\
\hline
\end{tabular}

Notes: ${ }^{a}$ Values are expressed as the mean \pm standard deviation $(\mathrm{g})$. Statistically different from the vehicle control group; $* P<0.05 ; * * P<0.01$. Abbreviations: $\mathrm{ZnO}^{\mathrm{sM20}(-)}, 20 \mathrm{~nm}$ negatively-charged $\mathrm{ZnO}$; NPs, nanoparticles. 
Table 4 Food consumption of the pregnant rats treated with $\mathrm{ZnO}^{\text {SM20(-) NPs }}$

\begin{tabular}{|c|c|c|c|c|}
\hline \multirow[t]{2}{*}{ Dose (mg/kg body weight/day) } & \multicolumn{4}{|l|}{$\mathrm{ZnO}^{\mathrm{SM20(-)}} \mathrm{NPs}$} \\
\hline & Vehicle (citrate) & 100 & 200 & 400 \\
\hline Number of pregnant females & 22 & 21 & 24 & 25 \\
\hline Gestation day 0 & $19.00 \pm 4.47^{\mathrm{a}}$ & $20.94 \pm 3.73$ & $21.26 \pm 2.30$ & $21.83 \pm 3.14$ \\
\hline Gestation day 2 & $23.90 \pm 3.00$ & $25.78 \pm 3.19$ & $26.52 \pm 3.82$ & $25.23 \pm 2.87$ \\
\hline Gestation day 4 & $26.32 \pm 3.23$ & $26.32 \pm 3.28$ & $26.7 I \pm 3.33$ & $27.43 \pm 2.92$ \\
\hline Gestation day 6 & $27.07 \pm 3.94$ & $26.02 \pm 3.50$ & $25.42 \pm 3.34$ & $23.63 \pm 3.66$ \\
\hline Gestation day 8 & $27.94 \pm 4.48$ & $27.56 \pm 3.55$ & $28.26 \pm 4.86$ & $27.56 \pm 4.08$ \\
\hline Gestation day 10 & $28.10 \pm 3.12$ & $26.30 \pm 3.62$ & $26.7 I \pm 5.6$ & $28.70 \pm 6.55$ \\
\hline Gestation day 12 & $29.05 \pm 4.34$ & $27.77 \pm 4.26$ & $27.95 \pm 377$ & $28.65 \pm 5.64$ \\
\hline Gestation day 14 & $29.48 \pm 3.42$ & $29.13 \pm 4.14$ & $28.48 \pm 2.67$ & $27.77 \pm 3.89$ \\
\hline Gestation day 16 & $31.53 \pm 2.93$ & $31.44 \pm 3.32$ & $30.77 \pm 3.94$ & $30.49 \pm 5.97$ \\
\hline Gestation day 18 & $30.18 \pm 6.17$ & $31.65 \pm 2.76$ & $31.12 \pm 2.77$ & $29.32 \pm 3.56$ \\
\hline
\end{tabular}

Note: a $\vee$ alues are expressed as the mean \pm standard deviation (g).

Abbreviations: $\mathrm{ZnO}^{\mathrm{SM} 2(-)}, 20 \mathrm{~nm}$ negatively-charged $\mathrm{ZnO}$; NPs, nanoparticles.

in the fetuses of the treatment groups, no significant difference was found in the number of fetuses with visceral variations or in the number of litters with affected fetuses between the groups (Table 8). No skeletal malformations were observed in any of the groups (Table 9). Although there were some types of skeletal variations, including incomplete ossification of skull, dumbbell ossification of the thoracic centrum, bipartite ossification of the thoracic centrum, asymmetric

Table 5 Absolute and relative organ weights of pregnant rats treated with $\mathrm{ZnO}^{\text {SM20(-) NPs }}$

\begin{tabular}{|c|c|c|c|c|c|}
\hline \multirow[t]{2}{*}{ Dose (mg/kg body weight/day) } & \multirow[t]{2}{*}{ Unit } & \multicolumn{4}{|l|}{$\mathrm{ZnO}^{\text {SM20(-) NPs }}$} \\
\hline & & Vehicle (citrate) & 100 & 200 & 400 \\
\hline Number of pregnant females & & 22 & 21 & 24 & 25 \\
\hline Body weight at term (g) & & $422.2 \pm 20.86^{a}$ & $418.3 \pm 26.38$ & $4 \mid 7.1 \pm 26.73$ & $406.4 \pm 23.97$ \\
\hline \multirow[t]{2}{*}{ Liver } & $(g)$ & $16.00 \pm 1.27$ & $15.20 \pm 1.25$ & $|4.80 \pm| .5 \mid$ & $14.48 \pm 1.27^{* *}$ \\
\hline & $(g \%)$ & $3.79 \pm 0.19$ & $3.63 \pm 0.20$ & $3.54 \pm 0.20 * *$ & $3.56 \pm 0.18 * *$ \\
\hline \multirow[t]{2}{*}{ Kidney, left } & $(g)$ & $1.07 \pm 0.10$ & $1.06 \pm 0.11$ & $1.07 \pm 0.19$ & $1.08 \pm 0.08$ \\
\hline & $(g \%)$ & $0.25 \pm 0.02$ & $0.25 \pm 0.03$ & $0.26 \pm 0.04$ & $0.27 \pm 0.02$ \\
\hline \multirow[t]{2}{*}{ Kidney, right } & (g) & $1.10 \pm 0.10$ & $1.09 \pm 0.10$ & $1.07 \pm 0.09$ & $1.09 \pm 0.10$ \\
\hline & $(g \%)$ & $0.26 \pm 0.02$ & $0.26 \pm 0.02$ & $0.26 \pm 0.02$ & $0.27 \pm 0.02$ \\
\hline \multirow[t]{2}{*}{ Spleen } & (g) & $0.7 I \pm 0.11$ & $0.66 \pm 0.10$ & $0.65 \pm 0.08$ & $0.66 \pm 0.12$ \\
\hline & $(g \%)$ & $0.17 \pm 0.03$ & $0.16 \pm 0.02$ & $0.16 \pm 0.02$ & $0.16 \pm 0.03$ \\
\hline \multirow[t]{2}{*}{ Adrenal gland, left } & (g) & $0.042 \pm 0.007$ & $0.044 \pm 0.009$ & $0.045 \pm 0.007$ & $0.048 \pm 0.007$ \\
\hline & $(g \%)$ & $0.009 \pm 0.004$ & $0.011 \pm 0.002$ & $0.01 \mathrm{I} \pm 0.002$ & $0.012 \pm 0.002 * *$ \\
\hline \multirow[t]{2}{*}{ Adrenal gland, right } & (g) & $0.039 \pm 0.007$ & $0.04 I \pm 0.008$ & $0.045 \pm 0.006^{*}$ & $0.045 \pm 0.007 *$ \\
\hline & $(g \%)$ & $0.009 \pm 0.002$ & $0.010 \pm 0.002$ & $0.011 \pm 0.002 *$ & $0.011 \pm 0.002 * *$ \\
\hline \multirow[t]{2}{*}{ Ovary, left } & (g) & $0.068 \pm 0.015$ & $0.070 \pm 0.020$ & $0.07 I \pm 0.015$ & $0.066 \pm 0.021$ \\
\hline & $(g \%)$ & $0.016 \pm 0.004$ & $0.017 \pm 0.005$ & $0.017 \pm 0.004$ & $0.016 \pm 0.005$ \\
\hline \multirow[t]{2}{*}{ Ovary, right } & (g) & $0.07 I \pm 0.01 I$ & $0.077 \pm 0.020$ & $0.068 \pm 0.016$ & $0.073 \pm 0.014$ \\
\hline & $(g \%)$ & $0.017 \pm 0.003$ & $0.018 \pm 0.005$ & $0.016 \pm 0.004$ & $0.018 \pm 0.004$ \\
\hline \multirow[t]{2}{*}{ Brain } & (g) & $1.94 \pm 0.21$ & $1.97 \pm 0.06$ & $1.99 \pm 0.09$ & $1.93 \pm 0.10$ \\
\hline & $(g \%)$ & $0.46 \pm 0.05$ & $0.47 \pm 0.04$ & $0.48 \pm 0.03$ & $0.48 \pm 0.03$ \\
\hline \multirow[t]{2}{*}{ Pituitary gland } & (g) & $0.015 \pm 0.005$ & $0.016 \pm 0.003$ & $0.016 \pm 0.004$ & $0.018 \pm 0.016$ \\
\hline & $(g \%)$ & $0.004 \pm 0.001$ & $0.004 \pm 0.001$ & $0.004 \pm 0.001$ & $0.004 \pm 0.004$ \\
\hline \multirow[t]{2}{*}{ Lung } & (g) & $1.33 \pm 0.15$ & $1.34 \pm 0.11$ & $1.32 \pm 0.10$ & $1.31 \pm 0.10$ \\
\hline & $(g \%)$ & $0.32 \pm 0.03$ & $0.32 \pm 0.03$ & $0.32 \pm 0.02$ & $0.32 \pm 0.02$ \\
\hline \multirow[t]{2}{*}{ Heart } & (g) & $1.16 \pm 0.27$ & $1.13 \pm 0.10$ & $1.05 \pm 0.18$ & $1.09 \pm 0.12$ \\
\hline & $(g \%)$ & $0.27 \pm 0.07$ & $0.27 \pm 0.02$ & $0.25 \pm 0.05$ & $0.27 \pm 0.02$ \\
\hline \multirow[t]{2}{*}{ Uterus (gravid) } & (g) & $81.75 \pm 8.62$ & $80.07 \pm 8.80$ & $84.18 \pm 9.67$ & $85.75 \pm 12.99$ \\
\hline & $(g \%)$ & $19.38 \pm 1.96$ & $19.14 \pm 1.76$ & $20.17 \pm 1.83$ & $21.09 \pm 2.83$ \\
\hline
\end{tabular}

Notes: ${ }^{V}$ Values are expressed as the mean \pm standard deviation $(\mathrm{g})$. Statistically different from the vehicle control group; $* P<0.05 ; * * P<0.01$.

Abbreviations: $\mathrm{ZnO}^{\mathrm{SM} 20(-)}, 20 \mathrm{~nm}$ negatively-charged $\mathrm{ZnO}$; NPs, nanoparticles; g\%, relative weight of organ-to-body weight (g). 
Table 6 Caesarean section data from pregnant rats treated with $\mathrm{ZnO}^{\mathrm{SM20(-)}} \mathrm{NPs}$

\begin{tabular}{|c|c|c|c|c|}
\hline \multirow[t]{2}{*}{ Dose (mg/kg body weight/day) } & \multicolumn{4}{|l|}{$\mathrm{ZnO}^{\text {SM20(-) NPs }}$} \\
\hline & Vehicle (citrate) & 100 & 200 & 400 \\
\hline Number of dams & 22 & 21 & 24 & 25 \\
\hline Number of corpora lutea & $16.36 \pm 2.36^{\mathrm{a}}$ & $17.48 \pm 3.27$ & $17.79 \pm 3.36$ & $17.56 \pm 2.75$ \\
\hline Number of implantation sites & $14.73 \pm 1.55$ & $14.43 \pm 1.43$ & $15.21 \pm 1.77$ & $15.04 \pm 1.93$ \\
\hline Implantation rate (\%) & $90.85 \pm 9.27$ & $84.61 \pm 13.62$ & $87.34 \pm|3.3|$ & $86.70 \pm 11.53$ \\
\hline Fetal deaths & $0.73 \pm 1.03$ & $0.7 I \pm 0.85$ & $0.58 \pm 0.78$ & $0.52 \pm 0.82$ \\
\hline \multicolumn{5}{|l|}{ Resorption } \\
\hline Early & $0.64 \pm 1.05$ & $0.62 \pm 0.80$ & $0.42 \pm 0.58$ & $0.40 \pm 0.65$ \\
\hline Late & $0.09 \pm 0.29$ & $0.10 \pm 0.44$ & $0.13 \pm 0.45$ & 0 \\
\hline Dead fetuses & 0 & 0 & $0.04 \pm 0.20$ & $0.12 \pm 0.33$ \\
\hline Litter size & $14.0 \pm 1.7$ & $13.7 \pm 1.6$ & $14.6 \pm 1.7$ & $14.5 \pm 1.9$ \\
\hline Male/Female & $154 / 154$ & $151 / 137$ & $183 / 168$ & $194 / 169$ \\
\hline Sex ratio & 1.00 & 1.10 & 1.09 & 1.15 \\
\hline \multicolumn{5}{|l|}{ Fetal weight (g) } \\
\hline Male & $4.08 \pm 0.18$ & $4.11 \pm 0.29$ & $4.05 \pm 0.26$ & $4.10 \pm 0.38$ \\
\hline Female & $3.84 \pm 0.23$ & $3.94 \pm 0.30$ & $3.82 \pm 0.23$ & $3.89 \pm 0.26$ \\
\hline Placental weight (g) & $0.58 \pm 0.06$ & $0.58 \pm 0.05$ & $0.57 \pm 0.07$ & $0.56 \pm 0.04$ \\
\hline
\end{tabular}

Note: ${ }^{2}$ Values are expressed as the mean \pm standard deviation $(\mathrm{g})$.

Abbreviations: $\mathrm{ZnO}^{\mathrm{sM} 2(-)}, 20 \mathrm{~nm}$ negatively-charged $\mathrm{ZnO}$; NPs, nanoparticles.

Table 7 External alterations in fetuses from pregnant rats treated with $\mathrm{ZnO}^{\text {SM20(-) }} \mathrm{NPs}$

\begin{tabular}{|c|c|c|c|c|}
\hline \multirow[t]{2}{*}{ Dose (mg/kg body weight/day) } & \multicolumn{4}{|l|}{$\mathrm{ZnO}^{\mathrm{SM} 2(-)} \mathrm{NPs}$} \\
\hline & Vehicle (citrate) & 100 & 200 & 400 \\
\hline Litters examined & 22 & 21 & 24 & 25 \\
\hline \multicolumn{5}{|l|}{ External examination } \\
\hline Fetuses examined & 308 & 288 & 351 & 363 \\
\hline Fetuses with malformations (\%) ${ }^{\mathrm{a}}$ & 0 & 0 & 0 & 0 \\
\hline Litters affected $(\%)^{\mathrm{b}}$ & 0 & 0 & 0 & 0 \\
\hline Fetuses with variations $(\%)^{\mathrm{a}}$ & $6(1.92)$ & $5(1.74)$ & $4(1.14)$ & $3(0.83)$ \\
\hline Litters affected $(\%)^{b}$ & $5(22.73)$ & $3(14.29)$ & $4(16.67)$ & $2(8.00)$ \\
\hline Hematoma & 6 & 4 & 4 & 2 \\
\hline Hypoplasia of tail & 0 & I & 0 & 0 \\
\hline Short tail & 0 & 0 & 0 & I \\
\hline
\end{tabular}

Notes: ${ }^{\mathrm{A} A}$ single fetus may be represented more than once when listing individual defects. ${ }^{\mathrm{b}}$ Includes litters with one or more affected fetuses.

Abbreviations: $\mathrm{ZnO}^{\mathrm{SM} 20(-)}, 20 \mathrm{~nm}$ negatively-charged $\mathrm{ZnO}$; NPs, nanoparticles.

Table 8 Visceral alterations in fetuses from rats treated with $\mathrm{ZnO}^{\mathrm{SM} 20(-)} \mathrm{NPs}$

\begin{tabular}{|c|c|c|c|c|}
\hline \multirow[t]{2}{*}{ Dose (mg/kg body weight/day) } & \multicolumn{4}{|l|}{$\mathrm{ZnO}^{\mathrm{SM} 20(-)} \mathrm{NPs}$} \\
\hline & Vehicle (citrate) & 100 & 200 & 400 \\
\hline Litters examined & 22 & 21 & 24 & 25 \\
\hline \multicolumn{5}{|l|}{ Visceral examination } \\
\hline Fetuses examined & 147 & 139 & 171 & 176 \\
\hline Fetuses with malformations (\%) & 0 & 0 & 0 & 0 \\
\hline Litters affected (\%) & 0 & 0 & 0 & 0 \\
\hline Fetuses with variations (\%) ${ }^{\mathrm{a}}$ & $120(81.63)$ & II $15(82.73)$ & 119 (69.59) & 139 (78.98) \\
\hline Litters affected $(\%)^{b}$ & $18(81.82)$ & I8 (85.7I) & $23(95.83)$ & $23(92.00)$ \\
\hline Misshapen thymus & 8 & 5 & 14 & 18 \\
\hline \multicolumn{5}{|l|}{ Ureter abnormality } \\
\hline Grade I & 52 & 48 & 37 & 59 \\
\hline Grade II & 36 & 49 & 51 & 46 \\
\hline Grade III & 23 & 8 & 13 & 14 \\
\hline Dilated renal pelvis & 1 & I & 0 & 1 \\
\hline Large kidney & 0 & I & 0 & 0 \\
\hline Ectopic kidney & 0 & 3 & 4 & 1 \\
\hline
\end{tabular}

Notes: ${ }^{\mathrm{A}} \mathrm{A}$ single fetus may be represented more than once when listing individual defects. ${ }^{b}$ Includes litters with one or more affected fetuses.

Abbreviations: $\mathrm{ZnO}^{\mathrm{sM20}(-)}, 20 \mathrm{~nm}$ negatively-charged $\mathrm{ZnO}$; NPs, nanoparticles. 
Table 9 Skeletal variations in fetuses from rats treated with $\mathrm{ZnO}^{\text {SM20(-) NPs }}$

\begin{tabular}{|c|c|c|c|c|}
\hline \multirow[t]{2}{*}{ Dose (mg/kg body weight/day) } & \multicolumn{4}{|l|}{$\mathrm{ZnO}^{\mathrm{SM} 20(-)} \mathrm{NPs}$} \\
\hline & Vehicle (citrate) & 100 & 200 & 400 \\
\hline Litters examined & 22 & 21 & 24 & 25 \\
\hline \multicolumn{5}{|l|}{ Skeletal examination } \\
\hline Fetuses examined & 161 & 149 & 180 & 187 \\
\hline Fetuses with malformations (\%) ${ }^{\mathrm{a}}$ & 0 & 0 & 0 & 0 \\
\hline Litters affected $(\%)^{b}$ & 0 & 0 & 0 & 0 \\
\hline Fetuses with variations $(\%)^{a}$ & II (6.83) & $7(4.70)$ & II (6.II) & $17(9.10)$ \\
\hline Litters affected $(\%)^{\mathrm{b}}$ & $8(36.36)$ & $6(28.57)$ & $7(29.17)$ & $9(36.00)$ \\
\hline \multicolumn{5}{|l|}{ Skull } \\
\hline Incomplete ossification & $\mathrm{I}$ & 0 & 0 & 0 \\
\hline \multicolumn{5}{|l|}{ Thoracic centrum } \\
\hline Dumbbell ossification & 1 & 0 & 0 & 2 \\
\hline Bipartite ossification & 0 & 0 & 0 & I \\
\hline Asymmetric & 0 & 1 & 1 & I \\
\hline Incomplete ossification & 2 & 1 & 2 & 6 \\
\hline \multicolumn{5}{|l|}{ Rib } \\
\hline Supernumerary & 5 & 2 & 7 & 5 \\
\hline \multicolumn{5}{|l|}{ Sternebra } \\
\hline Asymmetric & 2 & 3 & 1 & 0 \\
\hline Incomplete ossification & I & 0 & I & 2 \\
\hline \multicolumn{5}{|l|}{ Lumbar vertebra } \\
\hline Incomplete ossification & 0 & 0 & 0 & 1 \\
\hline
\end{tabular}

Notes: ${ }^{a} \mathrm{~A}$ single fetus may be represented more than once when listing individual defects. $\operatorname{lincludes~litters~with~one~or~more~affected~fetuses.~}$ Abbreviations: $\mathrm{ZnO}^{\mathrm{SM} 2(-)}, 20 \mathrm{~nm}$ negatively-charged $\mathrm{ZnO}$; NPs, nanoparticles.

thoracic centrum, supernumerary rib, asymmetric sternebra, incomplete ossification of the sternebra, and incomplete lumbar ossification, no significant difference was observed in the number of fetuses with skeletal variations or in the number of litters with affected fetuses between the groups.

\section{Discussion}

Recently, information on the toxicity of $\mathrm{ZnO} \mathrm{NPs}$, including liver damage, membrane injury, cytotoxicity, and

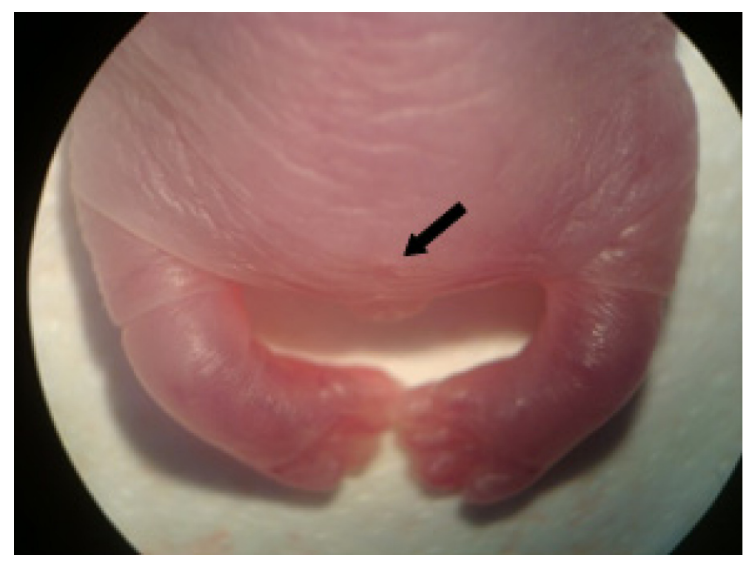

Figure 3 External alteration in the fetus from a pregnant rat treated with $\mathrm{ZnO}^{\text {SM20(-) }}$ NPs at a dose of $100 \mathrm{mg} / \mathrm{kg} /$ day.

Note: Hypoplasia tail (absent; arrow).

Abbreviations: $\mathrm{ZnO}^{\text {SM20(-) }}, 20 \mathrm{~nm}$ negatively-charged $\mathrm{ZnO}$; NPs, nanoparticles. inflammatory response, ${ }^{39,40}$ is increasing, culminating in several toxicity studies of $\mathrm{ZnO}$ NPs with different biological systems, such as bacteria ${ }^{41,42}$ and mammalian cells. ${ }^{43}$ However, the evidence for reproduction/developmental toxicity in mammalians was limited, while $\mathrm{ZnO}$ NPs are being used extensively in various commercial applications ${ }^{44,45}$ due to the specific physicochemical and electrical properties of nanomaterials. ${ }^{46}$ Considering that humans could be easily exposed to $\mathrm{ZnO}$ NPs intentionally or unintentionally, it

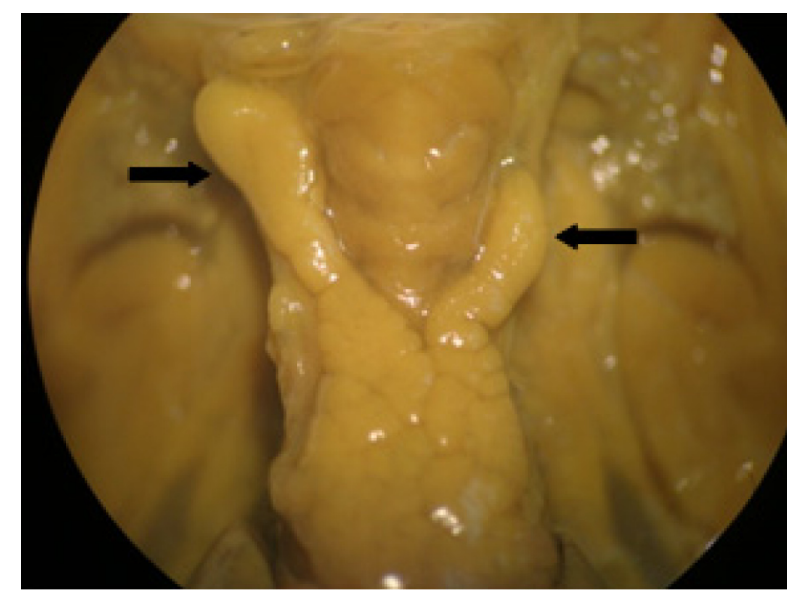

Figure 4 Visceral alteration in the fetus from a rat treated with vehicle. Notes: Misshapen thymus (arrow). Vehicle $=20$ nM 4-(2-hydroxyethyl)-I-piperazineethanesulfonic acid (HEPES) buffer containing $1 \%$ sodium citrate. 


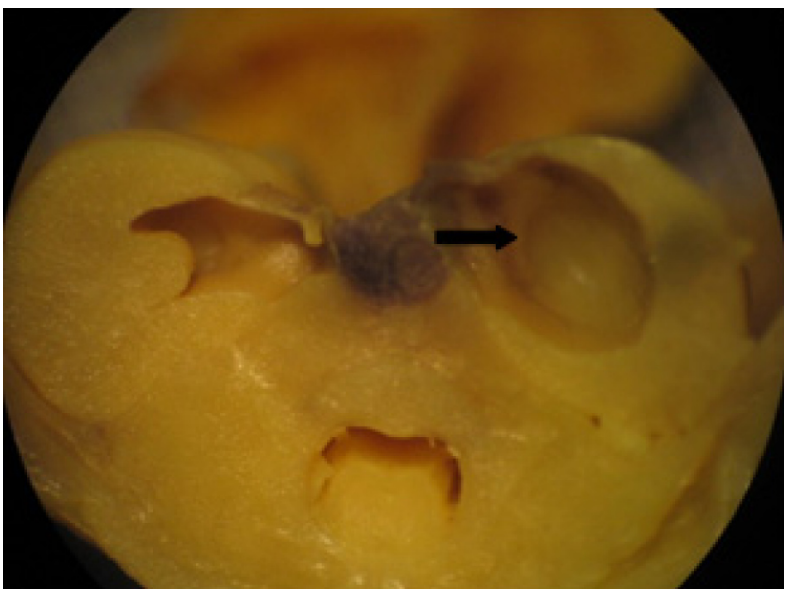

Figure 5 Visceral alteration in the fetus from a rat treated with vehicle. Notes: Dilated renal pelvis (arrow). Vehicle $=20$ nM 4-(2-hydroxyethyl)-I-piperazineethanesulfonic acid (HEPES) buffer containing $1 \%$ sodium citrate.

would be highly desirable and necessary to have a better understanding of their possible toxicity.

This study was conducted to investigate the maternal and developmental toxic potentials of ZnO NPs oral administrated to SD rats at dose levels of $0,100,200$, and $400 \mathrm{mg} / \mathrm{kg} /$ day over the period of GDs 5-19 of pregnancy. The $\mathrm{ZnO}$ NPs were capped with organic ligands, citrate molecules, which are widely used capping agents for inorganic NPs for enhancing their surface charge property. ${ }^{14-16}$ Citrate was also used to reduce the aggregation and sedimentation of NPs and to obtain a well-dispersed suspension of ZnO NPs for oral administration. ${ }^{47}$ It is well known that citrates and citric acid are important ligands for metal ions in biological systems, forming strong bonds with various ions, such as $\mathrm{Zn}^{2+}, \mathrm{Fe}^{3+}$, $\mathrm{Ca}^{2+}, \mathrm{Mg}^{2+}$, and $\mathrm{Ag}^{2+} \cdot{ }^{48}$

The results showed that a 15-day repeated oral dosing of $\mathrm{ZnO}^{\mathrm{SM} 20(-)} \mathrm{NPs}$ during pregnancy revealed maternal toxicity at $200 \mathrm{mg} / \mathrm{kg} /$ day and $400 \mathrm{mg} / \mathrm{kg} /$ day, but it was not teratogenic at a maternally toxic dose. Although salivation was observed in all treated groups, it was not considered to be related to the $\mathrm{ZnO}^{\mathrm{SM} 2(-)} \mathrm{NP}$ treatment, since salivation was observed sporadically and was not dose dependent. This finding may be attributed to irritation stress of $\mathrm{ZnO} N P s$. $\mathrm{ZnO}^{\mathrm{SM} 20(-)} \mathrm{NPs}$ induced significant maternal toxicity in the $200 \mathrm{mg} / \mathrm{kg} /$ day and $400 \mathrm{mg} / \mathrm{kg} /$ day groups, which was evidenced by suppressed body weight gain, decreased liver weights and, increased adrenal gland weights. The suppressed body weight gain observed in the high-dose group might be a direct effect of $\mathrm{ZnO}^{\mathrm{SM} 20(-)} \mathrm{NPs}$ on pregnant dams, since the gravid uterine weight of the $400 \mathrm{mg} / \mathrm{kg} /$ day group at term was similar to that of the control group.

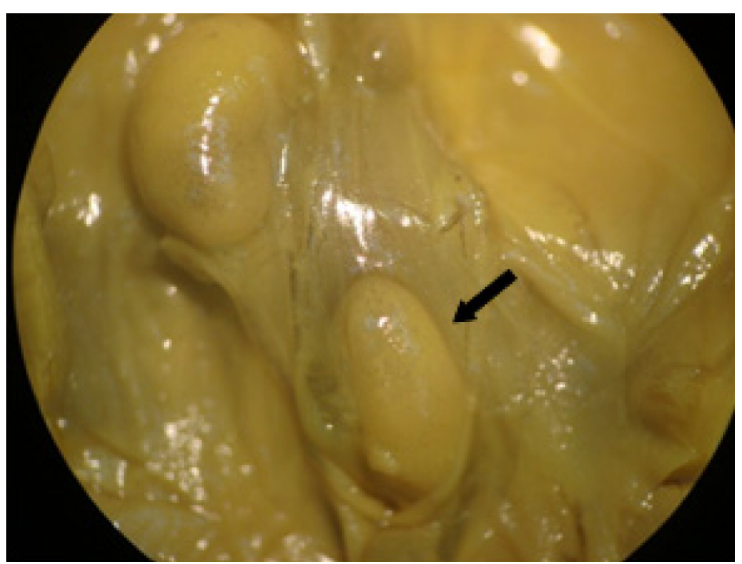

Figure 6 Visceral alteration in the fetus from a rat treated with $\mathrm{ZnO}^{\mathrm{SM20(-)}} \mathrm{NPs}$ (100 mg/kg).

Note: Ectopic kidney (malpositioned; arrow).

Abbreviations: $\mathrm{ZnO}^{\mathrm{SM} 20(-)}, 20 \mathrm{~nm}$ negatively-charged $\mathrm{ZnO}$; NPs, nanoparticles.

In general reproductive toxicity studies, it was well known that body weight and organ weight would be sensitive indicators of potentially toxic chemicals. ${ }^{49-51}$ The significant decreases in absolute and relative liver weights in the $400 \mathrm{mg} / \mathrm{kg}$ group, and the relative liver weight in the $200 \mathrm{mg} / \mathrm{kg}$ group, were attributed to the administration of $\mathrm{ZnO}^{\mathrm{SM} 20(-)} \mathrm{NPs}$, since this change was remarkable in comparison with the control group, revealing a clear-cut dose-response relationship. Earlier studies have shown the biodistribution of engineered NPs to the liver and kidney after uptake in the gastrointestinal tract. ${ }^{14,52,53}$ In the present study, the significant decreases in the absolute and relative weights of the liver observed in the $200 \mathrm{mg} / \mathrm{kg} / \mathrm{day}$ and $400 \mathrm{mg} / \mathrm{kg} /$ day groups were considered to be related to the $\mathrm{ZnO}^{(-)} \mathrm{NP}^{(20 \mathrm{~nm})}$ treatment, since the decrement was remarkable in comparison with the control group, showing clear-cut dose-dependent correlations. The significant increases in the relative adrenal gland weights observed in the $200 \mathrm{mg} / \mathrm{kg} /$ day and $400 \mathrm{mg} / \mathrm{kg} /$ day group were also considered to be a treatment-related effect, since these changes were different in comparison with the control group. The increased weight of the adrenal glands was considered to be related to induced stress responses by the administration of $\mathrm{ZnO}^{\mathrm{SM} 20(-)} \mathrm{NPs}$ and was consistent with decreased body weight gain in the group. Previous studies demonstrated that the function and weight of the adrenal glands were adversely affected by various stressful factors. ${ }^{54-57}$

Until now, a variety of studies have evaluated the toxic effects of $\mathrm{ZnO}$ nanomaterials either in vitro or in vivo. Yang et $\mathrm{al}^{58}$ demonstrated that there was an interrelationship between the particle size, shape, chemical composition, and 
toxicology effects of carbon black, single-wall carbon nanotube, silicon dioxide $\left(\mathrm{SiO}_{2}\right)$, and $\mathrm{ZnO}$ NPs in primary mouse embryo fibroblast cells. Xia et $\mathrm{al}^{59}$ reported that $\mathrm{ZnO}$ induced toxicity in RAW 264.7 and BEAS-2bB cell lines, leading to the generation of reactive oxygen species, oxidant injury, excitation of inflammation, and cell death. According to the bacterial toxicity study conducted with $\mathrm{ZnO}$ NPs,${ }^{60} \mathrm{ZnO}$ NPs damaged the bactericidal cell wall by increasing membrane permeability. In nematodes, ${ }^{61}$ manufactured ZnO NPs $(1.5 \mathrm{~nm})$ revealed toxicity, suggesting intracellular biotransformation by the NPs. In algae, ${ }^{62}$ comparable toxicities of nanoparticulate $\mathrm{ZnO}$, bulk $\mathrm{ZnO}$, and $\mathrm{ZnCl} 2$ were observed.

As to the morphological findings from the fetuses of $\mathrm{ZnO}^{\mathrm{SM} 20(-)}$ NP-treated dams, external, visceral, and skeletal variations were found in few fetuses. The observed fetal variations in the present study were not considered to be due to the administration of $\mathrm{ZnO}^{(-)} \mathrm{NPs}^{(20 \mathrm{~nm})}$ because they occurred at a very low incidence without a dose-response relationship, and they were sporadically observed in the normal control rat fetuses. ${ }^{63-65}$ Additionally, treatment-related fetal malformation was not found in all treated groups.

Meanwhile, the accumulation of $\mathrm{Zn}$ in the fetuses of the vehicle and $\mathrm{ZnO}^{\mathrm{SM} 20(-)} \mathrm{NP}$ dose group are shown in Figure 1. The NPs that were ingested into the body can be distributed to different regions because of their small size. After the exposure of $400 \mathrm{mg} / \mathrm{kg}$ /day group to $\mathrm{ZnO}^{\mathrm{SM} 20(-)}$ NPs, significantly increased Zn contents were not found in the $\mathrm{ZnO}^{\mathrm{SM} 20(-)} \mathrm{NP}$-treated rats in comparison with control. Although the increases in $\mathrm{Zn}$ concentrations in the exposed fetuses exhibited similar trends, intrauterine fetal growth/ development was considered to be weak.

In the present study, the effect of $\mathrm{ZnO}^{\mathrm{SM} 20(-)} \mathrm{NPs}$ on intrauterine growth and fetal survival, as well as on external, visceral, or skeletal morphology were analyzed. Lower mean maternal body weights and body weight gain relative to the control group were observed in a dose-dependent manner in the group that received $400 \mathrm{mg} / \mathrm{kg} /$ day of $\mathrm{ZnO}^{\mathrm{SM} 20(-)} \mathrm{NPs}$. Lower mean corrected body weight was noted in this group at necropsy. Also, decreased body weight gain was found at GD 20 of the $400 \mathrm{mg} / \mathrm{kg} /$ day group, which was considered to be toxicologically significant, even though the decreased body weight was not accompanied with changes in food consumption or embryo-fetal loss. On the contrary, as an example from similar studies, several positive effects of other NPs have been noted in the reproduction/developmental toxicity study. The intravenous administration of silica and titanium dioxide NPs into pregnant mice caused pregnancy complications. Mice had smaller uteral cornua and smaller fetuses than did the untreated controls. ${ }^{66}$ Also, when $50 \mathrm{mg} / \mathrm{kg} /$ day of silicon crystal NPs was injected, the NPs led to a reduction in body weight gain in pregnant rats and newborn rats at different stages of the experiment, but they had no effect on the other parameters of physical development of rat progeny and caused no teratogenic effects. ${ }^{67}$ On the other hand, when silver NPs (250 mg/kg/day) were orally injected, there was a relatively low toxic effect. ${ }^{68}$

Unpublished 90-day repeated oral dose and genotoxicity data from our previous studies were briefly summarized in our laboratory documents. The ZnO NPs did not cause any significant changes at the endpoints of repeated dose toxicity, including clinical observation, functional observation, body weight gain, water and food consumption, urinalysis, hematology, serum biochemistry, organ weight, toxicokinetic study, tissue distribution, and histopathology observed in the repeated study. In addition, 14-day recovery groups were set for the high-dose groups in both sexes. As no significant results were observed in the functional examination with respect to body weight gain, water and food consumption, urinalysis, necropsy, and organ weight, no significant effect was considered to be induced by the treatment of the $\mathrm{ZnO}$ NPs across these tested items. However, a dose-dependent deposition of $\mathrm{ZnO}$ NPs was also in the pancreas, glandular stomach, and eyes, indicating that the $\mathrm{ZnO}$ NPs were systemically distributed in the mammalian tissues. Furthermore, genotoxicity tests (unpublished data) of ZnO NPs did not show any gene mutation potential, in vitro chromosome aberration, or in vivo micronucleus. Meanwhile, an in vivo micronucleus test and an in vivo comet assay in the 90-day study yielded negative results, indicating that the test substance did not influence DNA damage.

\section{Conclusion}

In summary, the prenatal and developmental toxicity of negatively-charged $\mathrm{ZnO}$ NPs were tested in accordance with the OECD test guideline 414 and GLP principle. Pregnant female rats were orally treated with $\mathrm{ZnO}^{\mathrm{SM} 20(-)}$ NPs for 15 days, during GDs 5-19, with doses of $100 \mathrm{mg} /$ $\mathrm{kg} /$ day, $200 \mathrm{mg} / \mathrm{kg} /$ day, and $400 \mathrm{mg} / \mathrm{kg} /$ day. The results of this developmental toxicity study suggested that the administration of $\mathrm{ZnO}^{\mathrm{SM} 20(-)} \mathrm{NPs}$ to pregnant rats had no impact on embryo-fetal development in rats. Based on the results of this study, a dosage level of $100 \mathrm{mg} / \mathrm{kg} /$ day of $\mathrm{ZnO}^{\mathrm{SM} 20(-)}$ NPs was considered the no-observed-adverse-effect level for maternal toxicity, and the highest dose level of $400 \mathrm{mg} / \mathrm{kg}$ / day was considered the no-observed-adverse-effect level for embryo-fetal development. Although the result of the current 
study clearly showed the adverse effects of $\mathrm{ZnO}^{\mathrm{SM} 20(-)} \mathrm{NPs}$ for the mother, information on the effects of $\mathrm{ZnO}$ NPs on reproduction/development was not sufficient at this time.

\section{Acknowledgment}

This research was supported by a grant (10182MFDS991) from the Ministry of Food and Drug Safety in 2010-2011.

\section{Disclosure}

The authors report no conflicts of interest in this work.

\section{References}

1. Hernández Battez A, González R, Viesca JL, et al. CuO, $\mathrm{ZrO}_{2}$ and ZnO nanoparticles as antiwear additive in oil lubricants. Wear. 2008;265 (3-4):422-428.

2. Schilling K, Bradford B, Castelli D, et al. Human safety review of "nano" titanium dioxide and zinc oxide. Photochem Photobiol Sci. 2010;9(4): 495-509.

3. Gerloff K, Albrecht C, Boots AW, Förster I, Schins RPF. Cytotoxicity and oxidative DNA damage by nanoparticles in human intestinal Caco-2 cells. Nanotoxicology. 2009;3(4):355-364.

4. Jin T, Sun D, Su JY, Zhang H, Sue HJ. Antimicrobial efficacy of zinc oxide quantum dots against Listeria monocytogenes, Salmonella Enteritidis, and Escherichia coli O157:H7. J Food Sci. 2009;74(1): M46-M52.

5. He L, Liu Y, Mustapha A, Lin M. Antifungal activity of zinc oxide nanoparticles against Botrytis cinerea and Penicillium expansum. Microbiol Res. 2011;166(3):207-215.

6. Rasmussen JW, Martinez E, Louka P, Wingett DG. Zinc oxide nanoparticles for selective destruction of tumor cells and potential for drug delivery applications. Expert Opin Drug Deliv. 2010;7(9): 1063-1077.

7. John S, Marpu S, Li J, et al. Hybrid zinc oxide nanoparticles for biophotonics. J Nanosci Nanotechnol. 2010;10(3):1707-1712.

8. Drinker P, Thomson RM, Finn JL. Metal fume fever: IV. Threshold doses of zinc oxide, preventative measures, and the chronic effects of repeated exposures. J Ind Hyg Toxicol. 1927;9:331-345.

9. Blanc P, Wong H, Bernstein MS, Boushey HA. An experimental human model of metal fume fever. Ann Intern Med. 1991;114(11):930-936.

10. Baek M, Chung HE, Yu J, et al. Pharmacokinetics, tissue distribution, and excretion of zinc oxide nanoparticles. Int J Nanomedicine. 2012;7: 3081-3097.

11. Vaseem M, Umar A, Hahn YB. ZnO nanoparticles: growth, properties, and applications. In: Umar A, Hahn YB, editors. Metal Oxide Nanostructures and Their Applications. Valencia, CA: American Scientific Publishers; 2010:1-36.

12. Yah CS, Simate GS, Iyuke SE. Nanoparticles toxicity and their routes of exposures. Pak J Pharm Sci. 2012;25(2):477-491.

13. Wang L, Wang L, Ding W, Zhang F. Acute toxicity of ferric oxide and zinc oxide nanoparticles in rats. J Nanosci Nanotechnol. 2010;10(12): 8617-8624.

14. Wang J, Zhou G, Chen C, et al. Acute toxicity and biodistribution of different sized titanium dioxide particles in mice after oral administration. Toxicol Lett. 2007;168(2):176-185.

15. Wang B, Feng W, Wang M, et al. Acute toxicological impact of nano- and submicro-scaled zinc oxide powder on healthy adult mice. J Nanopart Res. 2008;10:263-276.

16. Surekha P, Kishore AS, Srinivas A, et al. Repeated dose dermal toxicity study of nano zinc oxide with Sprague-Dawley rats. Cutan Ocul Toxicol. 2012;31(1):26-32.
17. Yan G, Huang Y, Bu Q, et al. Zinc oxide nanoparticles cause nephrotoxicity and kidney metabolism alterations in rats. $J$ Environ Sci Health A Tox Hazard Subst Environ Eng. 2012;47(4):577-588.

18. Lu X, Liu Y, Kong X, Lobie PE, Chen C, Zhu T. Nanotoxicity: a growing need for study in the endocrine system. Small. 2013;9(9-10): $1654-1671$.

19. Iavicoli I, Fontana L, Leso V, Bergamaschi A. The effects of nanomaterials as endocrine disruptors. Int J Mol Sci. 2013;14(8):16732-16801.

20. Yamashita K, Yoshioka Y. [Safety assessment of nanomaterials in reproductive developmental field]. Yakugaku Zasshi. 2012;132(3):331-335. Japanese.

21. The Organization for Economic Cooperation and Development [webpage on the Internet]. Test no. 414: prenatal development toxicity study. Paris, France: The Organization for Economic Cooperation and Development; 2001. Available from: http://www.oecd-ilibrary.org/environment/ test-no-414-prenatal-development-toxicity-study_9789264070820-en. Accessed November 26, 2014.

22. The Organization for Economic Cooperation and Development. OECD Series on Principles of Good Laboratory Practice and Compliance Monitoring. Number 1. OECD Principles on Good Laboratory Practice (As Revised in 1997). Paris, France: The Organization for Economic Cooperation and Development; 1998. Available from: http://www. oecd.org/officialdocuments/publicdisplaydocumentpdf $/ ?$ cote=env/mc/ chem(98)17\&doclanguage=en. Accessed November 26, 2014.

23. KFDA. GLP principle of Korea Food and Drug Administration (KFDA Gosi 2009-183. KFDA. Ministry of Food and Drug Safety. Korea.

24. Degen A, Kosec M. Effect of $\mathrm{pH}$ and impurities on the surface charge of zinc oxide in aqueous solution. J Eur Ceram Soc. 2000;20(6): 667-673.

25. Oh JM, Park DH, Choy JH. Integrated bio-inorganic hybrid systems for nano-forensics. Chem Soc Rev. 2011;40(2):583-595.

26. Kim KM, Kim TH, Kim HM, et al. Colloidal behaviors of $\mathrm{ZnO}$ nanoparticles in various aqueous media. Toxicology and Environmental Health Sciences. 2012;4(2):121-131.

27. Chung HE, Yu J, Baek M, et al. Toxicokinetics of zinc oxide nanoparticles in rats. J Phys Conf Ser. 2013:429.

28. Yamada T, Hara M, Ohba Y, Inoue T, Ohno H. [Studies on implantation traces in rats. II. Staining of cleared uteri, formation and distribution of implantation traces]. Jikken Dobutsu. 1985;34(3):249-260. Japanese.

29. Menegola E, Broccia ML, Giavini E. Atlas of rat fetal skeleton double stained for bone and cartilage. Teratology. 2001;64(3):125-133.

30. Wilson JG. Methods for administering agents and detecting malformations in experimental animals. In: Wilson JG, Warkany J, editors. Teratology, Principles and Techniques. Chicago, IL: University of Chicago Press; 1965:262-277.

31. Nishimura K. A microdissection method for detecting thoracic visceral malformations in mouse and rat fetuses. Congenit Anom (Kyoto). 1974; $14: 23-40$.

32. Chahoud I, Buschmann J, Clark R, et al. Classification terms in developmental toxicology: need for harmonisation. Report of the Second Workshop on the Terminology in Developmental Toxicology Berlin, 27-28 August 1998. Reprod Toxicol. 1999;13(1):77-82.

33. Makris SL, Solomon HM, Clark R, et al. Terminology of developmental abnormalities in common laboratory mammals (version 2). Congenit Anom (Kyoto). 2009;49(3):123-246.

34. Weil CS. Selection of the valid number of sampling units and a consideration of their combination in toxicological studies involving reproduction, teratogenesis or carcinogenesis. Food Cosmet Toxicol. 1970;8(2):177-182.

35. Scheffé H. A method for judging all contrasts in the analysis of variance*. Biometrika. 1953;40(1/2):87-110.

36. Kruskal WH, Wallis WA. Use of ranks in one-criterion variance analysis. J Am Stat Assoc. 1952;47(260):583-621.

37. Fisher RA. Statistical Methods for Research Workers. 14th ed. Edinburgh, Scotland: Oliver and Boyd; 1970. 
38. Bryant PL, Schmid JE, Fenton SE, Buckalew AR, Abbott BD. Teratogenicity of 2,3,7,8-tetrachlorodibenzo-p-dioxin (TCDD) in mice lacking the expression of EGF and/or TGF-alpha. Toxicol Sci. 2001;62(1):103-114.

39. Sharma V, Singh P, Pandey AK, Dhawan A. Induction of oxidative stress, DNA damage and apoptosis in mouse liver after sub-acute oral exposure to zinc oxide nanoparticles. Mutat Res. 2012;745(1-2): 84-91.

40. Esmaeillou M, Moharamnejad M, Hsankhani R, Tehrani AA, Maadi H. Toxicity of $\mathrm{ZnO}$ nanoparticles in healthy adult mice. Environ Toxicol Pharmacol. 2013;35(1):67-71.

41. Miller RJ, Lenihan HS, Muller EB, Tseng N, Hanna SK, Keller AA. Impacts of metal oxide nanoparticles on marine phytoplankton. Environ Sci Technol. 2010;44(19):7329-7334.

42. Sinha R, Karan R, Sinha A, Khare SK. Interaction and nanotoxic effect of $\mathrm{ZnO}$ and $\mathrm{Ag}$ nanoparticles on mesophilic and halophilic bacterial cells. Bioresour Technol. 2011;102(2):1516-1520.

43. Wang HJ, Growcock AC, Tang TH, O’Hara J, Huang YW, Aronstam RS. Zinc oxide nanoparticle disruption of store-operated calcium entry in a muscarinic receptor signaling pathway. Toxicol In Vitro. 2010;24(7):1953-1961.

44. Shulin JI, Changhui YE. Synthesis, growth mechanism, and applications of zinc oxide nanomaterials. Journals of Materials Science and Technology. 2008;24(4):457-472.

45. Wang JL. Zinc oxide nanostructures: growth, properties and applications. J Phys Condens Matter. 2004;16:R829-R858.

46. Ajayan M, Zhou OZ. Applications of carbon nanotubes. Carbon Nanotubes: Topics in Applied Physics. 2001;80:391-425.

47. Leeuwenburgh SC, Ana ID, Jansen JA. Sodium citrate as an effective dispersant for the synthesis of inorganic-organic composites with a nanodispersed mineral phase. Acta Biomater. 2010;6(3):836-844.

48. Parkinson JA, Sun H. New approach to the solution chemistry of bismuth citrate antiulcer complexes. Chem Commun (Camb). 1998;(8): 881-882.

49. Andersen H, Larsen S, Spliid H, Christensen ND. Multivariate statistical analysis of organ weights in toxicity studies. Toxicology. 1999;136 (2-3):67-77.

50. Bailey SA, Zidell RH, Perry RW. Relationships between organ weight and body/brain weight in the rat: what is the best analytical endpoint? Toxicol Pathol. 2004;32(4):448-466.

51. Chung MK, Kim CY, Kim JC. Reproductive toxicity evaluation of a new camptothecin anticancer agent, CKD-602, in pregnant/lactating female rats and their offspring. Cancer Chemother Pharmacol. 2007;59(3):383-395.

52. Chen Z, Meng H, Xing G, et al. Acute toxicological effects of copper nanoparticles in vivo. Toxicol Lett. 2006;163(2):109-120.

53. Cui Y, Liu H, Zhou M, et al. Signaling pathway of inflammatory responses in the mouse liver caused by $\mathrm{TiO} 2$ nanoparticles. $J$ Biomed Mater Res A. 2011;96(1):221-229.

54. Odio MR, Maickel RP. Comparative biochemical responses of rats to different stressful stimuli. Physiol Behav. 1985;34(4):595-599.
55. Kioukia-Fougia N, Antoniou K, Bekris S, Liapi C, Christofidis I, Papadopoulou-Daifoti Z. The effects of stress exposure on the hypothalamic-pituitary-adrenal axis, thymus, thyroid hormones and glucose levels. Prog Neuropsychopharmacol Biol Psychiatry. 2002;26(5): 823-830.

56. Kim HY, Lee SB, Chung YH, et al. Evaluation of subchronic inhalation toxicity of dimethyl disulfide in rats. Inhal Toxicol. 2006;18(5): 395-403.

57. Ulrich-Lai YM, Figueiredo HF, Ostrander MM, Choi DC, Engeland WC, Herman JP. Chronic stress induces adrenal hyperplasia and hypertrophy in a subregion-specific manner. Am J Physiol Endocrinol Metab. 2006;291(5):E965-E973.

58. Yang H, Liu C, Yang D, Zhang H, Xi Z. Comparative study of cytotoxicity, oxidative stress and genotoxicity induced by four typical nanomaterials: the role of particle size, shape and composition. $J \mathrm{Appl}$ Toxicol. 2009;29(1):69-78.

59. Xia T, Kovochich M, Liong M, et al. Comparison of the mechanism of toxicity of zinc oxide and cerium oxide nanoparticles based on dissolution and oxidative stress properties. ACS Nano. 2008;2(10):2121-2134.

60. Huang Z, Zheng X, Yan D, et al. Toxicological effect of ZnO nanoparticles based on bacteria. Langmuir. 2008;24(8):4140-4144.

61. Ma H, Bertsch PM, Glenn TC, Kabengi NJ, Williams PL. Toxicity of manufactured zinc oxide nanoparticles in the nematode Caenorhabditis elegans. Environ Toxicol Chem. 2009;28(6):1324-1330.

62. Franklin NM, Rogers NJ, Apte SC, Batley GE, Gadd GE, Casey PS Comparative toxicity of nanoparticulate $\mathrm{ZnO}$, bulk $\mathrm{ZnO}$, and $\mathrm{ZnCl} 2$ to a freshwater microalga (Pseudokirchneriella subcapitata): the importance of particle solubility. Environ Sci Technol. 2007;41(24): 8484-8490.

63. Morita H, Ariyuki F, Inomata N, et al. Spontaneous malformations in laboratory animals: frequency of external, internal and skeletal malformations in rats, rabbits and mice*. Congenit Anom (Kyoto). 1987;27(2):147-206.

64. Hood RD. Handbook of Developmental Toxicology. New York, NY: Informa Healthcare; 1997.

65. Kim JC, Lee SJ, Bae JS, Park JI, Kim YB, Chung MK. Historical control data for developmental toxicity study in Sprage-Dawley rats. J Toxicol Public Health. 2001;17:83-90. Korean.

66. Yamashita K, Yoshioka Y, Higashisaka K, et al. Silica and titanium dioxide nanoparticles cause pregnancy complications in mice. Nat Nanotechnol. 2011;6(5):321-328.

67. Durnev AD, Solomina AS, Daugel-Dauge NO, et al. Evaluation of genotoxicity and reproductive toxicity of silicon nanocrystals. Bull Exp Biol Med. 2010;149(4):445-449.

68. Hong JS, Kim S, Lee SH, et al. Combined repeated-dose toxicity study of silver nanoparticles with the reproduction/developmental toxicity screening test. Nanotoxicology. 2014;8(4):349-362.
International Journal of Nanomedicine

\section{Publish your work in this journal}

The International Journal of Nanomedicine is an international, peerreviewed journal focusing on the application of nanotechnology in diagnostics, therapeutics, and drug delivery systems throughout the biomedical field. This journal is indexed on PubMed Central, MedLine, CAS, SciSearch $®$, Current Contents $\AA /$ Clinical Medicine,

\section{Dovepress}

Journal Citation Reports/Science Edition, EMBase, Scopus and the Elsevier Bibliographic databases. The manuscript management system is completely online and includes a very quick and fair peer-review system, which is all easy to use. Visit http://www.dovepress.com/ testimonials.php to read real quotes from published authors. 